\title{
The Effect of Gender Unemployment on Economic Growth: A Panel Data Analysis
}

\author{
Shairilizwan Taasim ${ }^{1} *$, Adrian Daud ${ }^{2}$ \\ ${ }^{1,2}$ Department of Social Science and Management Faculty of Humanities, Management and Science \\ ${ }^{2}$ Universiti Putra Malaysia, Malaysia
}

\begin{abstract}
Objective - Prior to the East ASEAN Growth Area (EAGA) in ASEAN, Brunei, Indonesia, Malaysia, and the Philippines (BIMP) took in an inflow of immigrants to support growth. The more they depended on foreign labour, the issue of gender inequality in the job sector became an issue that is hindering prosperity.

Methodology/Technique - The research was aimed to identify the relation between unemployment rate from the gender perspective and economic growth of BIMP-EAGA by using two methods, namely Fully Modified Ordinary Least Square (FMOLS) and Dynamic Ordinary Least Square (DOLS). Annual time series data for the period of 1990 to 2018 was employed.

Findings \& Novelty - The result was contrary to Okun's law which says that there is a negative relation between the male unemployment rate and GDP. This study found that the female unemployment rate did not affect GDP and was insignificant. Policies that benefit and increase the participation of female workers in the job sector should be enhanced to prepare a conducive environment for the economy.
\end{abstract}

Type of Paper: Empirical.

JEL Classification: E24, J16.

Keywords: Labour Force, Gender, Economic Growth, BIMP

Reference to this paper should be made as follows: Taasim, S; Daud, A. (2020). The Effect of Gender Unemployment on Economic Growth: A Panel Data Analysis, J. Bus. Econ. Review, 5(3) 94-103 https://doi.org/10.35609/jber.2020.5.3(3)

\section{Introduction}

Brunei, Indonesia, Malaysia and the Philippines are amongst the most fast-developing countries in Southeast Asian. These countries are famous as a sub-region, namely the East Asian Growth Area (EAGA). The economic performance of Brunei, Indonesia, Malaysia and the Philippines show many similarities, for example, they were affected during the economic crises, especially the 1985/1986 Oil Price Crisis, 1997/1998 Financial Crisis and 2009 World Economic Subprime Crisis. Despite the expansion of its economy was attracted in exchange of human resources. This effected numbers of foreigners' working in economic activities. One of the popular reasons for this was that the wages for foreign labour were much more economical, and it is given value-added for the firm, in some situations, the high numbers of incoming foreign labourers to developing countries such as these cause competition with the local labour force.

\footnotetext{
* Paper Info: Revised: October 30, 2020

Accepted: December 31, 2020

* Corresponding author: Shairilizwan Taasim

E-mail: shairil@upm.edu.my

Affiliation: Department of Social Science and Management Faculty of Humanities, Management and Science Universiti Putra Malaysia, Malaysis
} 


\section{Shairilizwan Taasim and Adrian Daud}

In the end, this situation impacts the existing labour force and therefore results in a higher rate of unemployment, Okun (1962) had statistically established a negative association between economic growth and unemployment. According to him, the rule of thumb was to examine the relationship between economic growth and jobs, whereby to achieve a $1 \%$ decline in the unemployment rate, real GDP must grow at approximately $2 \%$ faster than the rate of potential GDP. Meidani and Zabihi (2011) mentioned that the unemployment rate was positively related to per capita real annual gross domestic product (GDP). On the other hand, a high unemployment rate will give a multiplier effect on households and the country as well. According to Ernst and Berg (2009), the decreasing number of unemployed resulted in reducing poverty. To decrease dependence on the foreign labour force, several groups from the local labour force, especially female workers, need to be increased. Hui and Hashmi (2007) stated that in Singapore, the reduction in domestic labour supply growth was offset to some extent by a corresponding increase in female labour force participation.

Output and unemployment are two key variables of the business cycle (Peiró, Belaire-Franch, and Gonzalo, 2012). These variables are visibly highly beneficial to countries with full employment. Although there is much literature on gender disparities in labour participation and incomes, as stated by Peiró et al. (2012), the work on gender gaps in unemployment and the relationship between them and the business cycle is much sparser. Furthermore, according to Miles (2002), the barriers to participation and employment for women come from two main sources; larger cultures and families, and the state and employers. On the other hand, according to Kwiatkowsa (2012) although with a low level of education, the female labour force is faced with the most severe joblessness problems in the labour market as compared to young people. The government policies and roles were said to be the solution for increasing the participation of women in the labour force and reducing the level of dependence on foreign labour. The study by Albanesi and Sahin (2018) showed that labour force attachment is influenced by fiscal and social policies like the marginal tax on second earners or maternity leave laws, cross-country differences in unemployment rates are affected by these policies as well.

Table 1. Women participation levels in the labour force for Brunei, Indonesia, Malaysia and the Philippines (\% of the total labour force)

\begin{tabular}{|c|c|c|c|c|}
\hline Year & Brunei & Indonesia & Malaysia & Philippines \\
\hline 1991 & 33.04 & 36.35 & 35.94 & 37.99 \\
\hline 2000 & 40.76 & 38.18 & 35.64 & 38.29 \\
\hline 2010 & 41.42 & 38.18 & 34.85 & 39.03 \\
\hline 2015 & 42.17 & 38.09 & 37.95 & 39.39 \\
\hline 2019 & 42.89 & 38.95 & 38.37 & 38.46 \\
\hline
\end{tabular}

Source: International Labour Organization, 2020

According to Cotter, Defiore, Hermsen, Marsteller and Vanneman (1998), the demand for female labour had strong effects on some dimensions of gender stratification but weaker or nonexistent effects on others. The study found that female labour gave impact over multiple dimensions of gender stratification, which ranged across economic, family, demographic, ideological, political and educational systems. As stated by Shimada (2005), many workers migrate because they can get better working conditions. These situations show us selected developing countries, especially BIMP being one of the locations for large inflows of foreign workers. Table 1 shows the number of women labour force participation, in which less than 50\% of the total labour force in the market since 1991 and the trend parallel.

As there is a limited number of studies on the effect unemployment rate on gender on economic growth, this has become extremely motivating for researchers to address the issue of gender in unemployment for selected Southeast Asian countries. This motivation appears from one of BIMP-EAGA's vision is to create 
jobs for women and increase the number of women participating in the economy. We first examine an analysis based on FMOLS and DOLS. Both analyses are preferred for the OLS estimator because they have small sample sizes. Krusell et al. (2010) noted the importance of measurement error in labour market flow as the analysis does not focus on gender differences. Before we perform our analysis, we must ensure our model and technique are correct and not bias towards fulfilling the requirement.

The structure of this paper is as follows with 5 sections, including an introduction. Section 2 reviews recent studies on unemployment and gender issues; we provided the current situation of unemployment in Malaysia. Section 3 discusses the methodology and theories we developed to identify gender unemployment. Section 4 and 5 present the results and conclusion. We also discuss the limitation of the analysis in section 5 to conclude the whole paper.

\section{Literature Review}

This section discusses past literature related to the issue of gender unemployment and its impact on economic growth. It will also relate to issues of social development, especially the theory related to unemployment. According to Dankumo, Suryati, Oluwaseyi, and Onisanwa, (2019); Brada, Marelli, and Signorelli (2014), the relation between the unemployment rate and economic growth was negative. If a downturn occurred, the unemployment rate would increase, and this will expand into the local labour. A study that was conducted by Noor et al. (2007) revealed that a negative relation was found between unemployment and growth by using the ordinary least square (OLS). The study was conducted from 1970 to 2004 by using Augmented Dicker-Fuller (ADF) and Philip-Perron testings. The author conducted a study in Malaysia to identify whether an Okun Law relation exists and the findings showed that the Okun Law could be applied to explain the unemployment rate in Malaysia.

However, research by Enejoh and Tsauni (2017) showed a positive relationship between unemployment and output, and a positive impact on economic growth using Johansen and Ganger technique. This study shows us that in the short run, the results end up with a negative and insignificant impact. Additionally, the author mentioned, the impacts of unemployment due to economic growth was positive when the analysis conducted for a longer run. Meidani and Zabihi (2011) employed the autoregressive distributed lag (ARDL) method to analyse the effect of unemployment on the gross domestic product (GDP). The study showed that the unemployment rate was significant in determining GDP both in the long run and short run. Notably, Dankumo et al. (2019) studied Okun Law and governance in Nigeria, the study found that unemployment rate and corruption had a negative relationship with economic growth. The research proposed that prosperity amongst the Nigerians depended on the country's and government's stability to ensure a decrease in the unemployment rate.

The reform of the labour force should be considered for every policymaker to reduce unemployment rate because of the multiplier effect on economic growth. The most important thing is economic prosperity, and it should be shared among citizens with priority to local workers than foreigners. In the job sector, gender inequality is one of the aspects that has to be seriously considered for a developing country. Myatt and Murrell (1990) emphasised that the most important determinant of the female unemployment rate was the minimum wage level. This indicates that women are more sensitive to changes in the marginal opportunity cost of unemployment if their commitment to work was lower than men. The issue of female participation in the labour force discussed by Lewandowska (2018) mentions that the female unemployment was diverse in the geographical space and did not have a significant impact on the formation of its analysis variables in all districts. The study was conducted in Poland by using a spatial perspective during 2003-2016. From the analysis, female unemployment was getting lower. Hence the result of this analysis confirmed that noneconomic (social) factors largely affected the level of female unemployment in Poland in 2016. 


\section{Shairilizwan Taasim and Adrian Daud}

In regards to the issue of the existence and competitiveness offered by the female labour in the market, it shall be deemed not to be an issue in any way in Malaysia, as there is sufficient evidence that they are competent to co-operate and/ or compete with men. Aside from that, there are many other issues, especially in technical fields. According to Kwiatkowska (2012) said in Poland, that female participation in economic activity had become lower, and females faced the most severe joblessness problems in the market. We should realise that women's participation in the labour market is an opportunity for the country to reduce dependence on foreign labour. The reason being noted by Cotter et al. (1998), the demand for female labours did not affect marriage, divorce, fertility, women, political representation or gender attitudes. In China, the female labour force participation rate is high. Furthermore, a study by Yue (2016) showed that the rule of government by the Communist Party was an influencing factor towards female equality in all spheres of life. Additionally, the low rate of fertility in China is contributed by its high female labour participation rate.

Musiał-Karg (2017) notes that in most cases, unemployment was not a conscious choice for women. However, the effect of conditions prevailing on the labour market limits the chances for female employment. In Malaysia, numerous studies were conducted regarding inequality in gender, but there is no evidence of gender bias in the job sector. Kenayathulla (2016) there is little evidence of gender bias in Malaysia. The author conducted a study using the Engel curve and Hurdel model, and the findings show no significant a gender differential in intra-household educational expenditures and the Malaysian society is becoming more accepting of the idea of working females. Dependence on foreign labour does not affect the performance of a firm, although the wages for these categories lower, as shown in numerous studies (Lewandowska, 2018; Enejoh and Tsauni, 2017). Additionally, the study Belaounia, Tao, and Zhao, (2020) exhibit the impact of female labour among high-level positions giving firms positive outcomes, but it depends on a country's level of gender equality. The author conducted studies among public firms from 23 countries.

As stated by Lee and Parasnis (2014), the increase in labour force participation leads to an increase in unemployment. Once debated on this issue, one of the arising topics from education and gender is, which level of formal education effects to the dimensions of life (Mendolicchio and Rhein, 2014). Thus, topic gender and other structural differences are usually ignored in policy debates and in the measures adopted to fight youth unemployment, leading to the persistence of inequalities (Rodriguez-Modroño, 2019). Furthermore, Mendolicchio and Rhein (2014) mentioned that female unemployment is higher than those of men; this is because female incomes are probably more variable over time. Although in Malaysia gender inequality is no evidence with report and statistic, this paper will identify the terms of effects in regards to the rate of unemployment based on the gender aspect to economic growth. According to (Lee and Parasnis, 2014; Mendolicchio and Rhein, 2014) numbers of unemployment could have effects on the actual well-being of risk-averse individuals, and this will bring about the risk of a lost generation.

\section{Methodology}

In order to examine the effect of gender unemployment on economic growth, this study collected data from the World Bank's yearly database for 1990-2018. The long-run panel data cointegration relation technique was used on data from four (4) countries in the sub-region of BIMP. The study assumed Romer's (1989) model, which says that an economy grows exponentially. The study's basic empirical model is given by Equation (1): 
$\log \left(\mathrm{gdp}_{\mathrm{ft}}\right)=\alpha_{\mathrm{f}}+\beta_{1} \log \left(\right.$ male $\left._{\mathrm{ft}}\right)+\beta_{2} \log \left(\mathrm{female}_{\mathrm{ft}}\right)+\beta_{3}\left(\operatorname{trade}_{\mathrm{ft}}\right)+\mu_{\mathrm{ft}}$

Where, $\mathrm{i}=1,2, \ldots, \mathrm{F}$ and $\mathrm{t}=1,2, \ldots \mathrm{T}$ are notations for country and time. The dependent variable is the gross domestic product (GDP), and the independent variables are the level of gender unemployment and trade openness for each panel data. All variables were converted into a natural logarithm. Variable (af) is the country-specific fixed effect which helps to stabilise the analysis over time even with other factors. Sehrawat and Giri (2016) economic growth are measured by per capita real GDP, and it represents the actual size of economic activity in the countries. Besides the other variable, the study uses trade openness (import + export / GDP) as a tool for improving investment and promoting foreign direct investment (Tiwariet et al., 2013).

The equation was developed as a theoretical framework for our analysis as stated by Mendolicchio and Rhein (2014), a gender-based analysis could benefit to issues of female labour market participation and wage discrimination. Hence, prior to our model being conducted, the first steps were employed panel unit root test and panel cointegration test. Panel unit root test was the unit root test employed to test the stationary of data. Levin et al. (2002) or LLC and Im et al. (2003) or IPS were two methods that can be used to test data stationarity. Levin et al. (2002) generalised the individual unit root test for panel data by using heterogeneous serially correlated errors, fixed effects and individual deterministic trends. Im et al. (2003) proposed a panel unit root test that allows for a heterogeneous autoregressive coefficient under the alternative hypothesis.

The next analysis was Panel cointegration test. The cointegration among the variables was employed by using a test proposed by Pedroni (1999). The cointegration test checked for heterogenous intercepts and trend coefficients across cross-sections. If the variables were co-integrated, the next step for the analysis was to estimate cointegration based on FMOLS and DOLS. To strengthen the analysis, Kao's (1999) method was also utilised. Kao's test uses specific intercepts and homogenous coefficients on the first stage in crosssection regressors. According to Pedroni (1999), there were seven different statistical methods to test for relation cointegration in a heterogeneous panel.

Panel v-statistic: $\mathrm{Z}_{\mathrm{v}}=\mathrm{T}^{2} \mathrm{~N}^{3 / 2}\left(\sum_{i=1}^{N} \sum_{t=1}^{T} \widehat{K}^{-2}{ }_{11}, \mathrm{i} \hat{\mu}_{i t-1}^{2}\right)^{-1}$, Panel $\rho$ - statistic: $\mathrm{Z}_{\mathrm{p}}=\mathrm{T} \sqrt{N}$ $\left(\sum_{i=1}^{N} \sum_{t=1}^{T} \widehat{K}^{-2}{ }_{11} \mathrm{i}\left(\bar{\mu}_{l t-1}^{2}\right)^{-1} \sum_{i=1}^{N} \sum_{t=1}^{T} \hat{k}^{-2} 11, \mathrm{i}\left(\hat{\mu}_{i t-1} \Delta \hat{\mu}_{i t} \widehat{\Lambda}_{i}\right)\right.$, Panel t-statistic (non-parametric): $\mathrm{Z}_{\mathrm{t}}=$ $\left(\tilde{\sigma}^{2} \sum_{i=1}^{N} \sum_{t=1}^{T} \hat{k}^{-2} 11, \mathrm{i} \hat{\mu}_{i t-1}^{2}\right)^{-1 / 2} \quad \sum_{i=1}^{N} \sum_{t=1}^{T} \hat{k}^{-2} 11, i\left(\hat{\mu}_{i t-1} \Delta \hat{\mu}_{i t}-\hat{\theta}_{i}\right)$ and Panel t-statistic (parametric): $Z_{t}^{*}=\left(\hat{s}_{N, T}^{* 2} \sum_{i=1}{ }^{\mathrm{N}} \sum_{t=1}^{T} \hat{k}^{-2} 11, i \hat{\mu}_{i t-1}^{2}\right)^{-1 / 2} \sum_{i=1}^{N} \sum_{t=1}^{T} \hat{k}^{-2} 11, i \hat{\mu}_{i t-1}^{2} \Delta^{{ }^{*}}$ it For group statistic, they have three (3) analysis unit root. Group p-statistic: $\tilde{Z}_{p}=T N^{-1 / 2} \sum_{i=1}^{N}\left(\sum_{t=1}^{T} \hat{\mu}_{i t-1}^{2}\right)^{-1} \sum_{t-1}^{T}\left(\hat{\mu}_{i t-1} \Delta \hat{\mu}_{i t}-\hat{\theta}_{i}\right)$, group $\quad$ t-statistic $\quad$ (non-parametric): $\tilde{Z}_{t}=N^{-1 / 2} \sum_{i=1}{ }^{N}\left(\hat{\theta}_{i}^{2} \sum_{t=1}^{T} \hat{\mu}_{i t-1}^{2}\right)^{-1 / 2} \sum_{t=1}^{T}\left(\hat{\mu}_{i t-1} \Delta \hat{\mu}_{i t}-\hat{\theta}_{i}\right)$ and group t-statistic (parametric): $\hat{Z}_{t}^{*}=N^{-1 / 2} \sum_{i=1}^{N}\left(\sum_{t=1}^{T} \hat{s}^{* 2} \hat{\mu}_{i t-1}^{2 *}\right)^{-1 / 2} \sum_{t=1}^{N} \hat{\mu}_{i t-1}^{*} \Delta \hat{\mu}_{i t}^{*}$, where $\quad \hat{\theta}_{i}=\frac{1}{2}\left(\hat{\sigma}_{i}^{2}-\hat{s}_{i}^{2}\right) \quad$ and $\quad \tilde{s}_{N, T}^{* 2}=$ $\frac{1}{N} \sum_{i=1}^{N} \hat{S}^{* 2}$ 


\section{Shairilizwan Taasim and Adrian Daud}

After the panel cointegration test was conducted, the next step was panel FMOLS and DOLS. Pedroni (1999) used the following cointegration equation:

$X_{i}=\alpha_{i}+\beta_{1 i} Z_{1 i, t}+\ldots B_{m i} Z_{m i, t}+\mu_{i t}$

Where $\mathrm{x}$ and $\mathrm{Z}$ are assumed to be integrated of order one, $\alpha_{\mathrm{i}}$ and slope coefficients $\beta_{1 \mathrm{i}}, \ldots \mathrm{B}_{\mathrm{mi}}$ vary across of the panel. By using the same equation from (2), the standard OLS estimator is:

$\hat{\beta}_{N T}=\left(\sum_{i=1}^{N} \sum_{t=1}^{T}\left(x_{i, t}-\bar{x}_{i}\right)^{2}\right)^{-1} \sum_{i=1}^{N} \sum_{t=1}^{T}\left(x_{i, t}-\bar{x}_{i}\right)\left(y_{i, t}-\bar{y}_{i}\right)$

The standard OLS modification was employed once the panel cointegration by using Pedroni (1999) fulfiled the standard requirement, as shown in equation (4):

$\hat{\beta}_{F M}=\left(\sum_{i=1}^{N} \hat{L}_{22 i}^{-1} \sum_{t=1}^{T}\left(x_{i, t}-\bar{x}_{i}\right)^{2}\right)^{-1} \sum_{i=1}^{N} \hat{L}_{11 i}^{-1} \hat{L}_{22 i}^{-1}\left(\sum_{t=1}^{T}\left(x_{i, t}-\bar{x}_{i}\right) y_{i, t}^{*}-T \delta_{i}\right)$

where $y_{i, t}^{*}=\left(y_{i, t}-\bar{y}_{i}\right)-\left(\frac{\hat{L}_{21 i}}{\bar{L}_{22 l}}\right) \Delta x_{i, t}+\left(\frac{\hat{L}_{21 i}-\hat{L}_{22 i}}{\widehat{L}_{22 i}}\right) \beta\left(x_{i, t}-\bar{x}_{i}\right)$ and $\delta_{i}=\hat{I}_{2 l i}+\theta_{2 l i}^{0}\left(\hat{L}_{2 l i}\right)\left(\hat{I}_{22 i}+\right.$ $\theta_{22 i}^{0}$ ). The DOLS estimator extends to panel analysis (Kao \& Ching, 2000) for small samples and performs well in general for co-integrated panels. The DOLS estimator panel is obtained by using the following regression:

$y_{i, t}=\beta_{i}^{\prime} x_{i, t}+\sum_{j=-q}^{q} \partial_{i j} \Delta x_{i, t+j}+\tau l l^{\prime} D_{l i}+\varepsilon_{i, t}$

Where q denotes the numbers of leads/lags typically for some info criterion, Miti'c et al. (2017) mentioned that an advantage of the DOLS estimator was the ability to control endogeneity in the model as augmentation with lead and lagged differences of the regressor suppressing the endogenous feedback. FMOLS originally developed by Phillips and Hansen (1990) to provide optimal estimates of co-integrating regressions.

\section{Empirical results and discussion}

The described methodology was applied to the data. This section presents the results of data analysis which was run by using the statistical software E-views V.10. Before using the fully modified OLS, the data were tested for variable stationarity. Based on the panel unit root test presented by Table 2, it was concluded that all variables contained unit root at level and stationarity at the first difference. The results were based on the two-panel unit root tests designed by LLC and IPS for each selected variable with and without a trend. 


\section{Shairilizwan Taasim and Adrian Daud}

Table 2. Panel unit root test

\begin{tabular}{|c|c|c|c|c|c|c|c|c|}
\hline & \multicolumn{9}{|c|}{ At level } & \multicolumn{3}{c|}{ At 1st difference } \\
\cline { 2 - 8 } & $\begin{array}{c}\text { Without } \\
\text { trend }\end{array}$ & p-value & $\begin{array}{c}\text { With } \\
\text { trend }\end{array}$ & p-value & $\begin{array}{c}\text { Without } \\
\text { trend }\end{array}$ & p-value & $\begin{array}{c}\text { With } \\
\text { trend }\end{array}$ & p-value \\
\hline LLC & & & & & & & & \\
dgdpt & -0.01 & 0.49 & 0.89 & 0.82 & -5.22 & $0.00 *$ & -4.05 & $0.00^{*}$ \\
dmalet & -1.19 & 0.12 & -1.07 & 0.14 & -6.15 & $0.00^{*}$ & -5.69 & $0.00^{*}$ \\
dfemalet & -0.07 & 0.47 & -0.07 & 0.48 & -4.02 & $0.00^{*}$ & -3.82 & $0.00^{*}$ \\
TCt & -1.37 & 0.09 & -0.10 & 0.46 & -5.68 & $0.00^{*}$ & -4.79 & $0.00^{*}$ \\
\hline IPS & & & & & & & & \\
dgdpt & 1.89 & 0.97 & 0.51 & 0.69 & -4.56 & $0.00 *$ & -3.22 & $0.00^{*}$ \\
dmalet & -0.15 & 0.44 & 0.13 & 0.55 & -5.31 & $0.00 *$ & -4.92 & $0.00^{*}$ \\
dfemalet & -0.07 & 0.47 & -0.06 & 0.48 & -4.02 & $0.00 *$ & -3.82 & $0.00^{*}$ \\
TCt & -0.09 & 0.46 & -1.03 & 0.15 & -4.66 & $0.00 *$ & -3.46 & $0.00^{*}$ \\
\hline
\end{tabular}

Note: lgdpt is the gross domestic product while ECt and TCt are energy consumption and trade openness, respectively. P-Value $<0.05(* *),<0.01(*)$ indicate the rejection of the null hypothesis of no cointegration at $10 \%, 5 \%$, and $1 \%$ levels of significance, respectively.

Therefore, this condition permitted the use of Pedroni's (1999) and Kao's (1999) panel cointegration tests. Then, the study applied seven of Pedroni's and Kao's tests of panel cointegration, as discussed in the methodology section. The test results proved the hypothesis of no cointegration between the variables, as presented in Table 3. According to Liddle, B. (2012), the test includes regressing the variables along with the relevant cross-section intercepts and tests that the residues are organised in order one.

Table 3. Pedroni's (1999) and Kao's (1999) panel cointegration tests

\begin{tabular}{|c|c|c|c|c|c|c|c|c|}
\hline Test & $\begin{array}{c}\text { Panel v- } \\
\text { statistic }\end{array}$ & $\begin{array}{c}\text { Panel } \\
\text { rho- } \\
\text { Statistic }\end{array}$ & $\begin{array}{c}\text { Panel } \\
\text { PP- } \\
\text { Statistic }\end{array}$ & $\begin{array}{c}\text { Panel } \\
\text { ADF- } \\
\text { Statistic }\end{array}$ & $\begin{array}{c}\text { Group } \\
\text { rho- } \\
\text { Statistic }\end{array}$ & $\begin{array}{c}\text { Group } \\
\text { PP- } \\
\text { Statistic }\end{array}$ & $\begin{array}{c}\text { Group } \\
\text { ADF- } \\
\text { Statistic }\end{array}$ & $\begin{array}{c}\text { Kao } \\
\text { Test }\end{array}$ \\
\hline Statistic & -1.303 & -2.91 & -12.64 & -5.69 & -1.37 & -9.89 & -5.51 & -4.19 \\
& $(0.94)$ & $(0.05)^{* * *}$ & $(0.00)^{*}$ & $(0.00)^{*}$ & $(0.08)^{* * *}$ & $(0.00)^{*}$ & $(0.00)^{*}$ & $(0.00)^{*}$ \\
\hline
\end{tabular}

Note: P-values are shown in parentheses. All reported values are asymptotically normally distributed. Probability statistics are shown within parentheses. *,**,*** indicate rejection of the null hypothesis of no cointegration at 10 $\%(* * *), 5 \%(* *)$, and $1 \%(*)$ levels of significance, respectively.

As discussed in the methodology of Pedroni's (1999), it suggests two sets of test statistics: (i) a panel test based on the inter-dimensional approach (panel cointegration statistics), of which four statistics are calculated: the panel v-, rho-, PP-, and ADF-statistics; and (ii) a group test based on the inter-dimensional approach (group mean panel cointegration statistics), of which three statistics are calculated: the group rho-, PP-, and ADF-s. The FMOLS and DOLS results at the group level are presented in Table 4. The results suggested the existence of a long-term relationship between the variables. Moreover, it also suggested the existence of a long-run cointegration among the variables unemployment rate for male labour and trade openness. Based on the FMOLS and DOLS analysis, an increase in the gross domestic product of $1 \%$ gave an impact to trade openness by about $7.2 \%$, and this leads to economic growth. For female unemployment rates, the findings showed a positive relation with economic growth, but this relation was not significant in both panels analysis. This meant that female labour does not explain GDP performance. 


\section{Shairilizwan Taasim and Adrian Daud}

Table 4. FMOLS and DOLS panel

\begin{tabular}{|c|c|c|c|c|}
\hline \multirow{2}{*}{ Variable } & \multicolumn{2}{|c|}{ FMOLS } & \multicolumn{2}{c|}{ DOLS } \\
\cline { 2 - 5 } & Coefficient & P-value & Coefficient & P-value \\
\hline Male unemployment (Umt) & -0.33 & $0.01^{*}$ & -1.32 & $0.02^{* *}$ \\
\hline Female Unemployment (Uft) & 0.13 & $0.26(\mathrm{nt})$ & 0.65 & $0.14(\mathrm{nt})$ \\
\hline Trade Openness & 0.72 & $0.00^{*}$ & 0.66 & $0.00^{*}$ \\
\hline
\end{tabular}

Note: Gross domestic product is treated as the dependent variable. Mft, Uft and TCt are unemployment rate for male and female and trade openness, respectively. P-Value $<0.10(* * *),<0.05(* *),<0.01(*)$ (nt) not significant indicate the rejection of the null hypothesis of no cointegration at $10 \%, 5 \%$, and $1 \%$ levels of significance, respectively.

For the male unemployment rate, the relation was significant but negative in both models for the long run. Therefore, the researchers concluded that an increase of $1 \%$ in the gross domestic product caused the unemployment rate for male labour to decrease by 3.3\% (FMOLS) or 13.2\% (DOLS). The economic growth will lead to a decrease in the number of male unemployment in the sub-region. A study conducted by Albanesi and Şahin (2018) with cross-country study among Organization for Economic Co-operation and Development (OECD) countries, after the 1980s, the gender unemployment gap disappeared. However, during recessions, male unemployment typically exceeded that of females. This may be because mostly the female labour force participation rate was below $40 \%$, especially in this study among sub-region. According to Colonna (2015), in almost all countries, a much larger share of female employment was part-time as compared to male employment at an average of $12 \%$ for women and only $2 \%$ for men.

\section{Conclusion}

Gender participation in the job sectors has been a significant issue in the contemporary global economy. In order to achieve equality in the job sector among gender, the capabilities of the countries to solving the issue of unemployment was prioritised. The study investigated the effect of gender unemployment on economic growth by using panel data for a sub-region in ASEAN, notably known as BIMP-EAGA. In conclusion, it is evident that the female unemployment rate does not affect economic performance as compared to male unemployment rates. This can be due to the fact that even though the number of female labour force participation in the market was lower since the number of the women labour force was not fully utilised. Numerous studies suggested to decrease dependency on the foreign labour force in the local market, female labour force must be seen as an alternative to fill in places in the job sector.

Further studies can be conducted on this topic by using different data and analysis techniques to identify more issues on gender inequality in the job sector, especially the levels of female labour participation. Two parts need to be considered as a challenge towards decreasing the unemployment rate of a developing country. First is a limitation in the labour force, more so in terms of local employees due to limitation of skills and expertise within the local population. Second is the need to fulfil the demand from industries, in which many developing countries resort to foreign labour to ensure supply. 

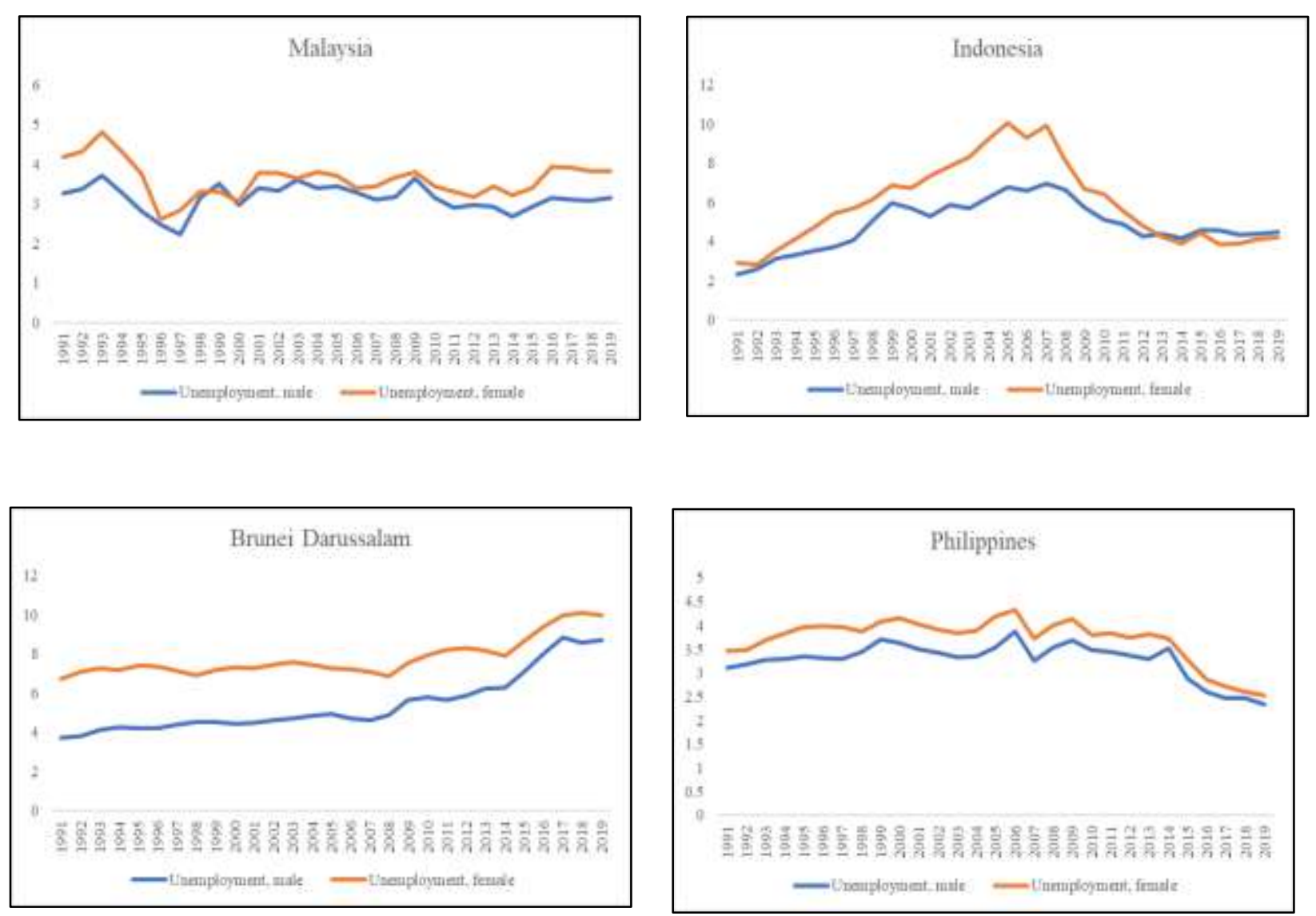

Figure 3. Trend unemployment rate by gender of Brunei, Indonesia, Malaysia and the Philippines from World Bank Report and International Labour Organisation 2020

\section{References}

Albanesi, S., \& Şahin, A. (2018). The gender unemployment gap. Review of Economic Dynamics, 30, $47-67$. https://doi.org/10.1016/j.red.2017.12.005

Brada, J. C., Marelli, E., \& Signorelli, M. (2014). Introduction: young people and the labor market: key determinants and new evidence. Comparative Economic Studies, 56(4), 556-566. https://doi.org/10.1057/ces.2014.30

Colonna, F., \& Marcassa, S. (2015). Taxation and female labor supply in Italy. IZA Journal of Labor Policy, 4(1), 5. https://doi.org/10.1186/s40173-015-0030-0

Cotter, D. A., DeFiore, J., Hermsen, J. M., Kowalewski, B. M., \& Vanneman, R. (1998). The demand for female labor. American Journal of Sociology, 103(6), 1673-1712. https://doi.org/10.1086/231404

Dankumo, A. M., Ishak, S., Oluwaseyi, Z. A., \& Onisanwa, I. D. (2019). Does Okun's Law Explain the Relationship between Economic Growth and Unemployment in Nigeria? (Does Okun Law explain the relationship between economic growth and Unemployment in Nigeria?). Malaysian Economic Journal, 53, 3. http://dx.doi.org/10.17576/JEM-2019-5303-12

Moh'd AL-Tamimi, K. A. Effect of Unemployment Rate on Growth Rate of Gross Domestic Product of Jordan. DOI: 10.5430/rwe.v10n3p217

Ernst, C., \& Berg, J. (2009). The role of employment and labour markets in the fight against poverty. Promoting ProPoor Growth: Employment.

Hui, W. T., \& Hashmi, A. R. (2007). Foreign labor and economic growth policy options for Singapore. The Singapore Economic Review, 52(01), 53-72.https://doi:10.1142/s0217590807002567

J. Bus. Econ. Review 5 (3) 94 - 103 (2020) 


\section{Shairilizwan Taasim and Adrian Daud}

Im, K. S., Pesaran, M. H., \& Shin, Y. (2003). Testing for unit roots in heterogeneous panels. Journal of econometrics, 115(1), 53-74. https://doi.org/10.1016/S0304-4076(03)00092-7

Kenayathulla, H. B. (2016). Gender differences in intra-household educational expenditures in Malaysia. International Journal of Educational Development, 46, 59-73.https://doi.org/10.1016/j.ijedudev.2015.10.007

Krusell, P., Mukoyama, T., Rogerson, R., \& Şahin, A. (2010). Aggregate labor market outcomes: The roles of choice and chance. Quantitative Economics, 1(1), 97-127.https://doi.org/10.3982/qe7

Kwiatkowska, W. (2012). Unemployment in problem groups on the labor market in Poland. Acta Universitatis Lodziensis, Folia Oeconomica, 268.

Liddle, B. (2012). The importance of energy quality in energy intensive manufacturing: Evidence from panel cointegration and panel FMOLS. Energy Economics, 34(6), 1819-1825.https://doi.org/10.1016/j.eneco.2012.07.013

Levin, A., Lin, C. F., \& Chu, C. S. J. (2002). Unit root tests in panel data: asymptotic and finite-sample properties. Journal of econometrics, 108(1), 1-24. https://doi.org/10.1016/S0304-4076(01)00098-7

Lee, G. H., \& Parasnis, J. (2014). Discouraged workers in developed countries and added workers in developing countries? Unemployment rate and labour force participation. Economic Modelling, 41, 90-98. https://doi.org/10.1016/j.econmod.2014.04.005

Lewandowska-Gwarda, K. (2018). Female unemployment and its determinants in Poland in 2016 from the spatial perspective. Oeconomia Copernicana, 9(2), 183-204.doi: 10.24136/oc.2018.010

Miles, R. (2002). Employment and unemployment in Jordan: The importance of the gender system. World development, 30(3), 413-427. https://doi.org/10.1016/S0305-750X(01)00123-1

Meidani, A. A. N., \& Zabihi, M. (2011). The dynamic effect of unemployment rate on per capita real gdp in iran. International journal of Economics and Finance, 3(5), 170. doi:10.5539/ijef.v3n5p170

Lewandowska-Gwarda, K. (2018). Female unemployment and its determinants in Poland in 2016 from the spatial perspective. Oeconomia Copernicana, 9(2), 183-204. https://doi.org/10.15290/cnisk.2017.02.03.07

Mitić, P., Munitlak Ivanović, O., \& Zdravković, A. (2017). A cointegration analysis of real GDP and CO2 emissions in transitional countries. Sustainability, 9(4), 568. https://doi.org/10.3390/su9040568

Mendolicchio, C., \& Rhein, T. (2014). The gender gap of returns on education across West European countries. International Journal of Manpower.https://doi.org/10.1108/ijm-02-2013-0026

Myatt, A., \& Murrell, D. (1990). The female/male unemployment rate differential. Canadian Journal of Economics, 312-322. https://doi.org/10.2307/135607

Noor, Z. M., Nor, N. M., \& Ghani, J. A. (2007). The relationship between output and unemployment in Malaysia: Does Okun's law exist. International Journal of Economics and Management, 1(3), 337-344.

Phillips, P. C., \& Hansen, B. E. (1990). Statistical inference in instrumental variables regression with I (1) processes. The Review of Economic Studies, 57(1), 99-125. https://doi.org/10.2307/2297545

Pedroni, P. (1999). Critical values for cointegration tests in heterogeneous panels with multiple regressors. Oxford Bulletin of Economics and statistics, 61(S1), 653-670. https://doi.org/10.1111/1468-0084.0610s1653

Peiró, A., Belaire-Franch, J., \& Gonzalo, M. T. (2012). Unemployment, cycle and gender. Journal of Macroeconomics, 34(4), 1167-1175. https://doi.org/10.1016/j.jmacro.2012.06.005

Rodriguez-Modroño, P. (2019). Youth unemployment, NEETs and structural inequality in Spain. International Journal of Manpower.https://doi.org/10.1108/ijm-03-2018-0098

Shimada, A. (2005). Foreign worker participation in labor markets and the economy's welfare. Journal of Policy Modeling, 27(3), 355-362.https://doi.org/10.1016/j.jpolmod.2005.01.005

Sehrawat, M., \& Giri, A. K. (2016). The impact of financial development on economic growth. International Journal of Emerging Markets.https://doi.org/10.1108/ijoem-11-2014-0172

Tiwari, A. K., Shahbaz, M., \& Islam, F. (2013). Does financial development increase rural-urban income inequality?. International Journal of Social Economics. https://doi.org/10.1108/03068291311283616

Yue, Y. (2016). Intergenerational Contracts and Female Labor Supply. Working paper. 